\title{
Relationship between the accumulation of sediment storage and debris-flow characteristics in a debris-flow initiation zone, Ohya landslide body, Japan
}

\author{
Fumitoshi Imaizumi ${ }^{1}$, Yuichi S. Hayakawa ${ }^{2}$, Norifumi Hotta ${ }^{3}$, Haruka Tsunetaka ${ }^{4}$, Okihiro Ohsaka ${ }^{1}$, and \\ Satoshi Tsuchiya ${ }^{1}$ \\ ${ }^{1}$ Faculty of Agriculture, Shizuoka University, Shizuoka, 422-8529, Japan \\ ${ }^{2}$ Center for Spatial Information Science, The University of Tokyo, Kashiwa, 277-0871, Japan \\ ${ }^{3}$ Graduate School of Agricultural and Life Sciences, The University of Tokyo, Tokyo, 113-8657, Japan \\ ${ }^{4}$ Graduate School of Life and Environmental Sciences, University of Tsukuba, Tsukuba, 305-8572, Japan \\ Correspondence to: Fumitoshi Imaizumi (imaizumi@shizuoka.ac.jp)
}

Received: 10 January 2017 - Discussion started: 16 January 2017

Revised: 6 October 2017 - Accepted: 11 October 2017 - Published: 14 November 2017

\begin{abstract}
Debris flows usually occur in steep mountain channels and can be extremely hazardous as a result of their destructive power, long travel distance, and high velocity. However, their characteristics in the initiation zones, which could possibly be affected by temporal changes in the accumulation conditions of the storage (i.e., channel gradient and volume of storage) associated with sediment supply from hillslopes and the evacuation of sediment by debris flows, are poorly understood. Thus, we studied the relationship between the flow characteristics and the accumulation conditions of the storage in an initiation zone of debris flow at the Ohya landslide body in Japan using a variety of methods, including a physical analysis, a periodical terrestrial laser scanning (TLS) survey, and field monitoring. Our study clarified that both partly and fully saturated debris flows are important hydrogeomorphic processes in the initiation zones of debris flow because of the steep terrain. The predominant type of flow varied temporally and was affected by the volume of storage and rainfall patterns. Fully saturated flow dominated when the total volume of storage was $<10000 \mathrm{~m}^{3}$, while partly saturated flow dominated when the total volume of the storage was $>15000 \mathrm{~m}^{3}$. Debris flows form channel topography which reflects the predominant flow types during debris-flow events. Partly saturated debris flow tended to form steeper channel sections $\left(22.2-37.3^{\circ}\right)$, while fully saturated debris flow tended to form gentler channel sections $\left(<22 \cdot 2^{\circ}\right)$. Such relationship between the flow type and the
\end{abstract}

channel gradient could be explained by a simple analysis of the static force at the bottom of the sediment mass.

\section{Introduction}

Debris flows often occur in steep mountain channels and can be extremely hazardous as a result of their destructive power, long travel distance, and high velocity (Lin et al., 2002; Cui et al., 2011). To lower the hazard of debris flow, field monitoring has been conducted in many torrents in the world including in Switzerland (McArdell et al., 2007; Berger et al., 2011b), Italy (Arattano, 1999; March et al., 2002; Arattano et al., 2012), the United States (McCoy et al., 2010; Kean et al., 2013), and China (Zhang, 1993; Hu et al., 2011). Many of these monitoring activities have been undertaken in the transportation zones of the debris flows, with only a few observations undertaken in their initiation zones, where the unstable sediment starts to move (Berti et al., 1999; McCoy et al., 2012; Kean et al., 2013). Thus, factors affecting debris-flow characteristics in the initiation zone (e.g., temporal changes in the solid fraction) are still unclear.

Debris flows can be classified into various types according to their flow dynamics, solid fractions, and material types (Coussot and Meunier, 1996; Hungr, 2005; Takahashi, 2007). Multiple flow types appear even in the same torrent (Imaizumi et al., 2005; Okano et al., 2012). However, in situ classification of debris-flow type is mainly based on moni- 
toring results obtained in the transportation zone. Field monitoring conducted at multiple sites along a debris-flow torrent have revealed that flow characteristics (e.g., solid fraction and boulder size) and discharge change as the flow migrates downstream and is affected by erosion and deposition (Takahashi, 1991; Berger et al., 2011b; Arattano et al., 2012). Thus, flow characteristics in the transportation zone possibly differ from those in the initiation zone. In the initiation zone, flows containing an unsaturated layer have also been observed during field monitoring (Imaizumi et al., 2005; McArdell et al., 2007; Imaizumi et al., 2016b). Such information is needed to explain the sequence of debris-flow processes from initiation in the headwaters to termination at the debris-flow fan.

The topography along debris-flow torrents reflects the characteristics of a debris-flow event (Whipple and Dunne, 1992; Coussot and Meunier, 1996; Imaizumi et al., 2016a). The curvature of the terrain can be used to determine the relationship between shear stress and shear strength (Staley et al., 2006). Many observations of the relationships between topography and flow characteristics have been made in the lower part of the debris-flow torrents, while such findings are limited in the debris-flow initiation zone. In many cases, the channel gradient in the initiation zone is greater than $20^{\circ}$ (VanDine, 1985; Pareschi et al., 2002; Gregoretti and Dalla Fontana, 2008; McCoy et al., 2013; Hürlimann et al., 2015). In terms of debris flows caused by the transportation of loose sediment on the floor of a valley, both the volume and grain size of debris-flow material (e.g., channel deposits and talus slope) change over time in association with the sediment supply from hillslopes, as well as the evacuation of sediment by debris flows and fluvial processes (Bovis and Jakob, 1999; Imaizumi et al., 2006; Berger et al., 2011a; Theule et al., 2012). Although some previous studies have investigated the relationship between the characteristics of the debris-flow material and initiation condition of a debris flow (Bovis and Jakob, 1999; Jakob et al., 2005; Schlunegger et al., 2009; Chen et al., 2012; Theule et al., 2012), only a few have considered the relationship between flow material and flow characteristics (Kean et al., 2013; Imaizumi et al., 2016b). The difficulty in monitoring debris flows in steep and dangerous initiation zones has prevented the collection of the field data needed to clarify the relationship between flow characteristics and flow material. In addition, the values of topographic indexes (e.g., slope gradient) are variable depending on the scale of the grid size used in the GIS analyses, because factors affecting the indexes are different among the scales of topography (Schmidt and Andrew, 2005; Loye et al., 2009; Pirotti and Tarolli, 2010; Drăguţ and Eisank, 2011). Thus, appropriate grid size for the analysis should be understood prior to discussing the relationship between the accumulation condition of flow material and flow characteristics.

In the debris-flow initiation zone at the Ichinosawa catchment within the Ohya landslide, Japan, field monitoring has been undertaken since 1998 (Imaizumi et al., 2005, 2006).
This site is suitable for monitoring because of the high debris-flow frequency (about three or four events per year) that occur due to the mobilization of storage (i.e., talus cone and channel deposits) around the channel. In addition, detailed topographic measurements by terrestrial laser scanning (TLS) have been undertaken periodically since 2011 (Hayakawa et al., 2016).

The overall aim of this study is to clarify the relationship between debris-flow type (i.e., fully and partly saturated flows) and the accumulation conditions of the storage (i.e., slope gradient and volume of storage). Our specific objectives were to explain the relationship between the slope gradient and sediment transport type by a simple analysis of the static force, clarify the effects of the accumulation conditions of the storage and rainfall pattern on the debris-flow type, determine the representative slope gradient of geomorphic units (i.e., rock slope, talus slopes, and the channel) based on analysis of digital elevation models (DEMs) with various grid sizes, and clarify the effects of the debris-flow type on the channel morphology.

\section{Slope gradient and type of sediment transport}

In this section, we describe our analysis of the balance of static force at the bottom of a sediment mass to assess the relationship between the slope gradient and the type of sediment transport, which is essential to understand the observation results and GIS analyses in this study. Shear stress at the bottom of a sediment mass needs to exceed shear strength for the sliding of a stable debris mass (Takahashi, 1991; Prancevic et al., 2014; Imaizumi et al., 2016c). Similarly, shear stress needs to exceed shear strength at the bottom of a traveling sediment mass for the continuity of travel (Takahashi, 1991; Watanabe, 1994), although its magnitude is sometimes lower than the shear stress needed for initial movement of the stable mass. Under the assumption that cohesion is negligible, shear stress $\tau$ and shear strength $\tau_{\mathrm{r}}$ at the bottom of sediment mass can be given as follows:

$$
\begin{aligned}
\tau & =\left\{\left(1-\eta_{\mathrm{w}}\right)\left[(1-n) \gamma_{\mathrm{s}}+n S \gamma_{\mathrm{w}}\right]\right. \\
& \left.+\eta_{\mathrm{w}}\left[(1-n) \gamma_{\mathrm{s}}+n \gamma_{\mathrm{w}}\right]\right\} \sin \alpha, \\
\tau_{\mathrm{r}} & =\left\{\left(1-\eta_{\mathrm{w}}\right)\left[(1-n) \gamma_{\mathrm{s}}+n S \gamma_{\mathrm{w}}\right]\right. \\
& \left.+\eta_{\mathrm{w}}\left[(1-n)\left(\gamma_{\mathrm{s}}-\gamma_{\mathrm{w}}\right)\right]\right\} \cos \alpha \tan \phi,
\end{aligned}
$$

where $\eta_{\mathrm{w}}$ is the ratio of the depth of the saturated zone $\left(h_{\mathrm{w}}-z_{1}\right)$ to the depth of the sediment mass $\left(h-z_{1}\right), h_{\mathrm{w}}$ is the height of the water table, $z_{1}$ and $h$ are the height at the bottom and surface of the sediment mass, respectively, $n$ is the porosity of sediment, $\gamma_{\mathrm{s}}$ is the force of gravity acting on a unit volume of sediment, $\gamma_{\mathrm{w}}$ is the force of gravity acting on a unit volume of water (or interstitial water for debris flow), $S$ is the degree of saturation in the unsaturated zone, $\alpha$ is the slope gradient, and $\phi$ is the effective internal angle of friction (Fig. 1). Note that $\alpha$ is the slope gradient of the potential 
sliding surface when we consider the initial movement of the stable mass, whereas it is the gradient of the surface topography when we consider the migration of the traveling sediment mass. The $n$ in the moving sediment mass is similar to that of stable sediment when dispersion of the sediment particles is not significant, while $n$ in the moving sediment mass greatly exceeds that of the stable sediment when the particle dispersion associated with collision among the particles is significant (e.g., fully saturated debris flow). Based on Eqs. (1) and (2), the critical condition for the movement of sediment mass $\left(\tau_{\mathrm{r}}=\tau\right)$ can be given as follows (Imaizumi et al., 2016c):

$$
\frac{\tan \alpha}{\tan \phi}=\frac{\left(1-\eta_{\mathrm{w}}\right)\left[(1-n) \gamma_{\mathrm{s}}+n S \gamma_{\mathrm{w}}\right]+\eta_{\mathrm{w}}\left[(1-n)\left(\gamma_{\mathrm{s}}-\gamma_{\mathrm{w}}\right)\right]}{\left(1-\eta_{\mathrm{w}}\right)\left[(1-n) \gamma_{\mathrm{s}}+n S \gamma_{\mathrm{w}}\right]+\eta_{\mathrm{w}}\left[(1-n) \gamma_{\mathrm{s}}+n \gamma_{\mathrm{w}}\right]}
$$

Based on the $\eta_{\mathrm{w}}$, three typical sediment transport types were considered: fully unsaturated $\left(\eta_{\mathrm{w}}=0\right)$, partly saturated $(0<$ $\left.\eta_{\mathrm{w}}<1\right)$, and fully saturated $\left(\eta_{\mathrm{w}}=1\right)$. In the case of $\eta_{\mathrm{w}}=0$, Eq. (3) is expressed as

$\tan \alpha=\tan \phi$

If the slope gradient $\tan \alpha$ exceeds $\tan \phi$, the sediment mass can move without any saturation (Fig. 1a). In other words, Eq. (4) expresses the lowest boundary of the slope gradient for the movement of the fully unsaturated sediment mass (hereafter referred to as $\alpha_{1}$ ). There are several types of sediment transport in fully unsaturated conditions, such as rockfall, dry granular flow, and dry ravel, which is the gravitational transport of ground surface materials by bouncing, rolling, and sliding (Carson, 1977; Dorren, 2003; Gabet, 2003). Although physical mechanisms between individual particles (i.e., rockfall and dry ravel) and flow of grains (i.e., dry granular flow) are different in terms of the interactions among particles, the slope gradient of talus slopes, which are formed by fully unsaturated sediment transport processes, is usually similar or slightly smaller than $\phi$ regardless of the transport type (Kirkby and Statham, 1975; Carson, 1977; Mangeney et al., 2007). Field surveys and laboratory experiments showed that pyroclastic flow, which is a fluid composed of a mixture of air and particles, sometimes reaches terrain with a slope smaller than $\phi$ (Yamashita and Miyamoto, 1993; Takahashi and Tsujimoto, 2000).

Next, we apply Eq. (3) to partly and fully saturated sediment transports including the debris flow. Field monitoring in many debris-flow torrents, including the Ohya landslide, showed that debris flows on debris deposits laid on the steep channels usually initiate by runoff as a surficial erosion (e.g., Coe et al., 2008; Gregoretti and Dalla Fontana, 2008; Degetto et al., 2015; Imaizumi et al., 2016b). In such cases, because sediment transport was affected by the hydrodynamic forces (Gregoretti, 2008; Gregoretti and Dalla Fontana, 2008; Prancevic et al., 2014), solid concentration

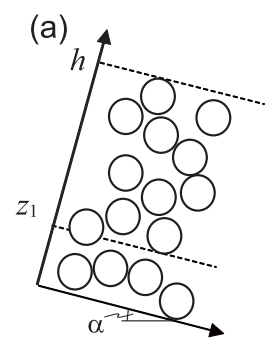

(c)
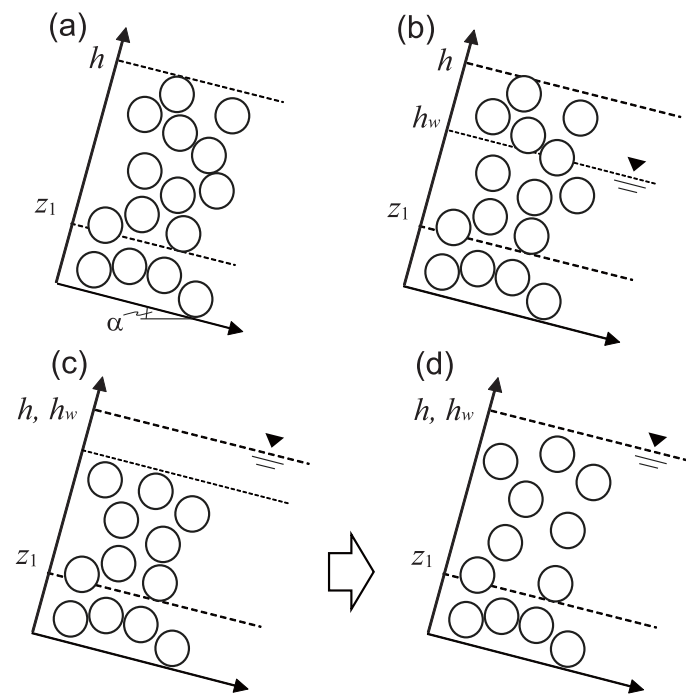

(d)

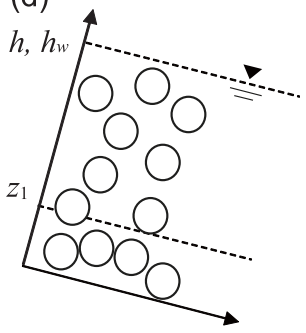

Figure 1. Schematic diagram of sediment transport types: (a) dry (fully unsaturated), (b) partly saturated, (c) surface flow over sediments, which triggers fully saturated sediment transport, and (d) fully saturated sediment transport. The $h, h_{\mathrm{W}}$, and $z_{1}$ in the figure indicate heights at the surface of the sediment mass, water level, and bottom of the sediment mass, respectively.

of the debris flow in their initial stage cannot be determined by the static force. Dynamic force in the flow is also important to explain debris-flow characteristics (Lanzoni et al., 2017). Therefore, static models cannot strictly explain all sediment transport processes in the debris-flow torrents. However, data related to flow dynamics and runoff discharge are limited in debris-flow initiation zones because of their unstable and dangerous monitoring environments (McCoy et al., 2013). The complexity of sediment transport processes in the initiation zones, in which both fully and partly saturated sediment transports occur because of the steep channels (Imaizumi et al., 2005, 2016c), also makes the full explanation of the processes difficult. The application of a simple static model (Eq. 3) approximating such complex processes, similarly with Takahashi (2014) and Prancevic et al. (2014), is considered to provide us perspective to comprehend overall processes.

The relationship between the slope gradient and the volumetric sediment concentration $(1-n)$ in a saturated sediment mass is given by substituting 1 into $\eta_{\mathrm{w}}$ in Eq. (3):

$\tan \alpha=\frac{(1-n)\left(\gamma_{\mathrm{s}}-\gamma_{\mathrm{w}}\right)}{(1-n) \gamma_{\mathrm{s}}+n \gamma_{\mathrm{w}}} \tan \phi$.

When we apply Eq. (5) to the debris flow, porosity $n$ can be expressed as $1-C$ using solid fraction $C$. The $n$ in the moving sediment mass becomes larger than the $n$ of storage when sediment particles start to disperse by collision with other particles (Hungr, 2005; Takahashi, 2014). By the transformation of Eq. (5), the relationship between the solid concentration in the steady-state flow (called equilibrium concen- 
tration) and the slope gradient is obtained (Takahashi, 1991, 2014; Egashira et al., 2001):

$$
C=\frac{\gamma_{\mathrm{w}} \tan \alpha}{\left(\gamma_{\mathrm{s}}-\gamma_{\mathrm{w}}\right)(\tan \phi-\tan \alpha)}
$$

An equation of the same structure as Eq. (6) can be obtained through the ratio between the basal bed shear stress and the basal normal stress that has a similar structure to the ratio between shear stress and strength (Lanzoni et al., 2017). Based on the flume experiments, particles are dispersed throughout the depth with the solid concentration expressed by Eq. (6) when the channel gradient is sufficiently high (i.e., $>15^{\circ}$ ) (Takahashi, 1978, 2014). At the same time, debris flows, in which particles are dispersed throughout the depth, are sometimes monitored in channels gentler than $10^{\circ}$ (McArdell et al., 2007), indicating the limitation of the static model in the explanation of complex natural processes.

Equation (5) just considers shear strength and shear stress at the bottom of the sediment mass, but does not consider the conditions of the fluid of the sediment mass. Thus, the sliding of the sediment mass without any fluid and the plug flow, where the upper layer in the sediment mass is not fluid, also satisfies Eq. (5). By substituting the porosity of the storage into $n$, Eq. (5) expresses the boundary of the slope gradient between fully and partly saturated sediment transports, where the solid fraction is same as that of storage (hereafter referred to as $\alpha_{2}$ ). When the slope gradient of the terrain ranges between $\alpha_{1}$ and $\alpha_{2}$, the transportation of a partly saturated sediment mass occurs (Fig. 1b) (Watanabe, 1994; Imaizumi et al., 2005, 2016c). Partly saturated sediment transport has also been observed in channels gentler than $\alpha_{2}$ (i.e., channel gradient $<10^{\circ}$ ) (McArdell et al., 2007; McCoy et al., 2010; Okano et al., 2012). However, the appearance of partly saturated sediment transport in such gentle channels is generally limited at the front of a surge. In torrents gentler than $\alpha_{2}$, the existence of surface flow over debris-flow material is required for the initiation of debris flow when we just consider static force (Fig. 1c) (Takahashi, 1991; Imaizumi et al., 2016c). Once sediment starts to move, it spreads throughout the flow (Fig. 1d). Thus, the volumetric solid concentration is lower than that in sediment storage $(1-n)$.

The explanations above (Eqs. 5 and 6) are also applicable to the relationship between the solid fraction of the debris flow and the channel gradient formed by erosion and deposition during passage of the debris flow (Takahashi, 1991, 2014). If the amount of water in the sediment mass from the upper channel reaches is constant, the slope gradient of the terrain approaches the gradient given by the substitution of $\eta_{\mathrm{w}}, n$, and $S$ of the sediment mass into Eq. (3) as a result of deposition and erosion.

In this study, we refer to any partly and fully saturated sediment transport processes as partly and fully saturated debris flows, respectively. Although some sediment transport processes at our monitoring site were not typical debris flows,

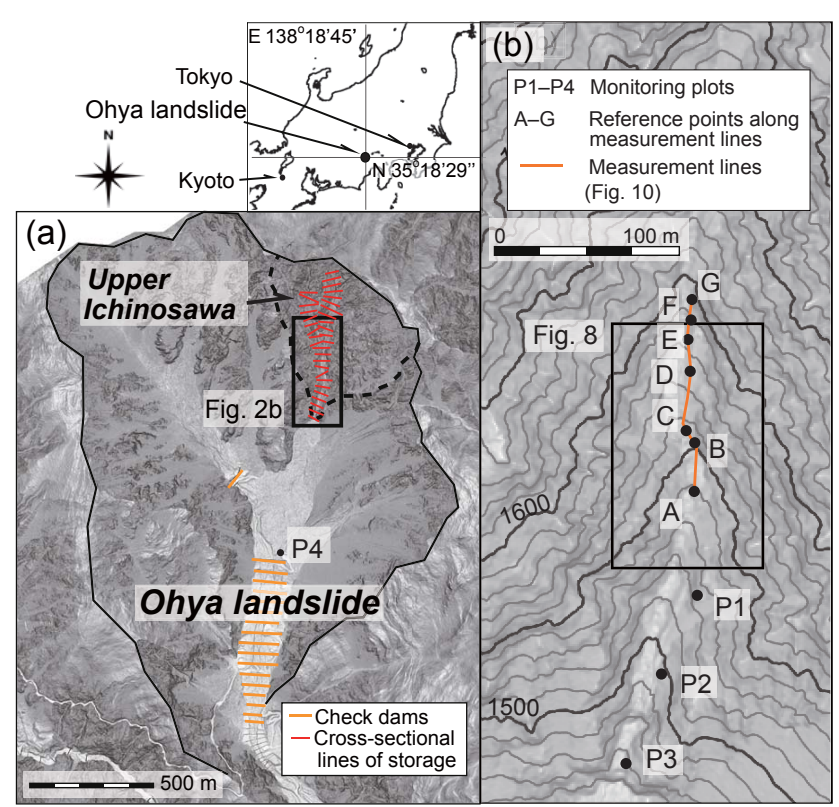

Figure 2. Map of the Ohya landslide and upper Ichinosawa catchment: (a) entire Ohya landslide, which is surrounded by a black solid line; (b) monitoring sites in the Ichinosawa upper catchment. Gentler and steeper terrains are expressed as light and dark colors, respectively. Cross-sectional lines used for estimation of the volume of the storage are shown as red lines in panel (a).

such as those composed of a mixture of sediment and water (Takahashi, 1991; Coussot and Meunier, 1996), we believe the processes at our study site directly or indirectly contributed to the initiation of debris flow.

\section{Study site}

We conducted field monitoring within the Ohya landslide in the southern Japanese Alps (Fig. 2). The Ohya landslide has an estimated the total volume of 120 million $\mathrm{m}^{3}$ and was initiated during an earthquake in AD 1707 (Tsuchiya and Imaizumi, 2010). The climate at the site is characterized by a high annual precipitation (about $3400 \mathrm{~mm}$ ) (Imaizumi et al., 2005). Heavy rainfall (i.e., total rainfall $>100 \mathrm{~mm}$ ) occurs during the rainy season from June to July and the autumn typhoon season (from August to October). The geological unit is Tertiary strata, which is composed of well-jointed sandstone and highly fractured shale. Unstable sediments have been supplied from outcrops into the channels in the landslide scar and have affected the initiation of debris flows since the original failure.

The Ohya landslide is currently composed of some subcatchments, and almost all debris flows in the Ohya landslide occur in one of the sub-catchments called the upper Ichinosawa catchment (Imaizumi et al., 2005). The total length of the channel is $\approx 650 \mathrm{~m}$ and the south-facing catchment (1450-1905 ma.s.1.) has an area of $0.22 \mathrm{~km}^{2}$. Most of the 
basin is characterized by high and steep slopes $\left(40-65^{\circ}\right)$. Seventy percent of the slope is scree and outcrop, whereas the remaining $30 \%$ is covered with forest, shrubs, and tussocks. Anthropogenic influences are absent in the catchment because of the harsh environmental conditions.

Unconsolidated debris, ranging from sand particles to boulders (Imaizumi et al., 2016c), is located in the channel bed and talus cones and is the source of debris-flow material (Imaizumi et al., 2006). The thickness of debris deposits, including large boulders ( $>1 \mathrm{~m})$, exceeds several meters in some sections. The freeze-thaw process promotes dry ravel and rockfalls, which are the predominant sediment infilling of the channels (Imaizumi et al., 2006). Most of the channel is covered by sediment when there is a large volume of storage accumulated in the upper Ichinosawa, while bedrock is exposed in some channel sections when the storage volume is low. The volume of storage displays seasonal changes caused by sediment supply from hillslopes in winter and early spring, and the evacuation of storage due to the occurrence of debris flow in summer and autumn (Imaizumi et al., 2006). The stored sediment has never been completely eroded by debris flows. Changes in the volume of storage at longer timescales (several years) occur by the timing of large debris flows with a volume $>15000 \mathrm{~m}^{3}$ that drastically decreased the volume of storage (Imaizumi et al., 2016c).

\section{Methodology}

\subsection{Debris-flow monitoring}

The monitoring system was installed in the study site in spring 1998 and consisted of a rain gauge, ultrasonic sensors, water pressure sensors, and a video camera in the section between P1 and P3 (Fig. 2) (Imaizumi et al., 2005). The video camera was initially monitored at $\mathrm{P} 4$ and then moved upstream to P2 in 2000 (Fig. 2). During the period of 1998 to 2001 , the video camera was programmed to take $0.75 \mathrm{~s}$ clips of video every $5 \mathrm{~min}$. In April 2001, this interval was shortened to $3 \mathrm{~min}$ to capture flow characteristics in more detail. In addition, continuous-monitoring cameras, whose recordings were initiated by wire motion sensors installed at several cross sections in the channel, were initially installed at P1 in 2003 and then at P3 and P2 in 2004 and 2005, respectively. The video camera system sometimes failed to capture debris flows because of mechanical problems due to harsh site conditions. We identified the timing of such debris flows based on changes in the topography observed by periodical photography with an interval of appropriately 1 week. Surface velocity of debris flows at $1 \mathrm{~s}$ intervals were obtained from the time required for boulders on the flow surface to pass through fixed channel sections (2.0-5.0 $\mathrm{m}$ length) on the video images. The flow depth average velocity was estimated from surface velocity multiplied by 0.6 , based on the velocity profile throughout the flows on movable beds obtained from

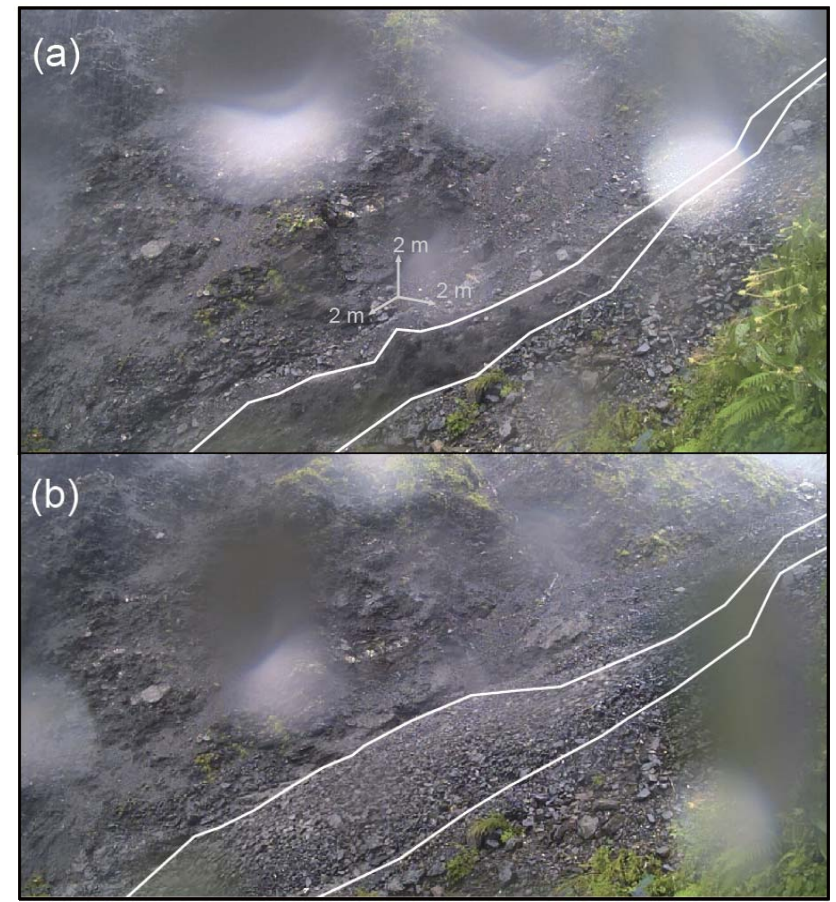

Figure 3. Images of fully and partly saturated debris flows captured by a time-lapse camera (TLC) at plot P2 in Fig. 2. (a) Fully saturated debris flow captured on 9 September 2015, 08:41 (LT). (b) Partly saturated debris flow captured on 9 September 2015, 07:43 (LT). Cobbles and boulders cover the flow surface of the partly saturated debris flow (Imaizumi et al., 2016b).

a physically based model by Takahashi $(1977,2014)$. Flow depth of debris flows at $1 \mathrm{~s}$ intervals was also obtained from the video image analysis by reading the level of the flow surface. Analysis points of the flow depth were set within the channel sections where changes in the channel bed topography were minimum. Changes in the cross-sectional area of flow were calculated from changes in flow depth and crosssection measurement of the channel topography. Discharge of debris flows were estimated from the cross-section area multiplied by the mean velocity of all layers.

Imaizumi et al. (2006) classified the flow phases during debris-flow events into two primary types: flows made up of mainly muddy water and those made up of mainly cobbles and boulders. The former flows are turbulent and are characterized by black surfaces due to high concentrations of silty sediment sourced from shale in the interstitial water (Fig. 3a). Because the matrix of boulders is filled with interstitial water, this flow is considered fully saturated (Fig. 1d). In contrast, the flow surface of the second type of flow is unsaturated, because muddy water is not identified in the matrix of the flow surface (Fig. 3b). Therefore, this type of flow is considered partly saturated (Fig. 1b). We visually identified temporal changes in the flow type during debris-flow events from 
Table 1. Date of TLS survey.

\begin{tabular}{|c|c|c|c|c|}
\hline Year & Date of survey & $\begin{array}{l}\text { Number of debris flow } \\
\text { after previous scanning }\end{array}$ & $\begin{array}{l}\text { Date of last debris- } \\
\text { flow event }{ }^{\mathrm{a}}\end{array}$ & $\begin{array}{r}\text { Average point spacing of } \\
\text { the cloud points (m) }\end{array}$ \\
\hline 2011 & 11 November & - & 14 October & 0.075 \\
\hline \multirow[t]{3}{*}{2012} & 14 May & 0 & - & 0.077 \\
\hline & 23 August & 2 & 22 June & 0.056 \\
\hline & 21 November & 3 & 30 September & 0.038 \\
\hline \multirow[t]{3}{*}{2013} & 10 May & 0 & - & 0.078 \\
\hline & 16 August & 0 & - & 0.040 \\
\hline & 19 November & 2 & 15 September & 0.057 \\
\hline \multirow[t]{3}{*}{2014} & 16 May & 0 & - & 0.094 \\
\hline & 17 August & 1 & 10 August & 0.066 \\
\hline & 28 November & 2 & 5 October & 0.085 \\
\hline \multirow[t]{3}{*}{2015} & 15 May & 0 & - & 0.094 \\
\hline & 23 August & 4 & 17 August & 0.083 \\
\hline & 4 December & 1 & 9 September & 0.130 \\
\hline
\end{tabular}

video images based on the existence of interstitial water on the flow surface.

Time-lapse cameras (TLCs; GardenWatchCam, Brinno, Taipei City, Taiwan) were installed around P1 and P2 in April 2013 as a backup for video camera monitoring. The number of cameras (1 to 6) differed among the various measurement periods. The intervals used for capturing images were also different among the measurement periods and for the various cameras, with a range from $1 \mathrm{~s}$ to $10 \mathrm{~min}$.

To identify the arrival of debris flow, semiconductor-type water pressure sensors, which monitored hydrostatic pressures up to $49 \mathrm{kPa}$ with an accuracy of $\pm 3 \%$, were also placed in holes dug in the bedrock of the channel bed at P3. Because water pressure sensors were sometimes washed away by debris flow, ultrasonic sensors with a measuring range from 120 to $600 \mathrm{~cm}$ (accuracy of $\pm 0.4 \%$ ) were installed to monitor the surface height of debris flows as the backup of water pressure sensors. Because the logging interval, which was set at $1 \mathrm{~min}$ for both types of sensors, was similar or longer than the duration of debris-flow surges (generally $20 \mathrm{~s}$ to $1 \mathrm{~min}$ ), these sensors were used not to calculate the discharge, but to identify occurrence of debris flows. Water pressure and flow height monitored by these instruments showed intense and abrupt changes during the passage of debris flows, whereas they increased and decreased slowly during rainfall-runoff events without the occurrence of debris flow.

Precipitation has been measured with a logging interval of $1 \mathrm{~min}$ using a tipping bucket rain gauge $(0.5 \mathrm{~mm}$ for one tip) located in an open area at P1 (Fig. 2b). We separated rainfall events by intermissions longer than $6 \mathrm{~h}$.

\subsection{Topographic data obtained by TLS}

To clarify temporal changes in the micro channel bed topography associated with the occurrence of debris flows, a TLS unit (GLS-1500, Topcon Co., Tokyo, Japan) was used to measure the topography of the valley axis (Fig. 2) (Hayakawa et al., 2016). Based on the specifications, the maximum measurable distance of the TLS unit is $500 \mathrm{~m}$ (for target objects with a $90 \%$ reflectance), with accuracies of $6^{\prime \prime}$ for angle and $4 \mathrm{~mm}$ for distance (at $150 \mathrm{~m}$ range). From November 2011, field measurements were undertaken in spring, summer, and autumn for 4 years (Table 1). For each measurement, the scanner was set at two positions and was correctly leveled with its internal tilt sensor (giving an angle accuracy of $\left.6^{\prime \prime}\right)$. One was at the downstream side of the target area (P1 in Fig. 2) and the other at the upstream side of the target area (around point D in Fig. 2). The two point clouds measured from different scan positions were registered using at least five reference targets placed between the two scan positions with accuracies of $0.5-6 \mathrm{~mm}$. The point spacing of cloud points ranged from 0.038 to $0.130 \mathrm{~m}$ (Table 1); thus, the point densities ranged from 59.5 to $689.9 \mathrm{pts} \mathrm{m}^{-2}$ (average $249.6 \mathrm{pts} \mathrm{m}^{-2}$ ). The geographic coordinates (Japan Plane Rectangular CS VIII, EPSG: 2450) of two targets, selected as georeference points, were measured with global navigation satellite system (GNSS) receivers (GeoXH 6000, Trimble, Sunnyvale, CA, USA; or GRS-1, Topcon Co., Japan; accurate to a range of $10-63 \mathrm{~mm}$ in $X, Y$ or $Z$ ). The baseline solution was calculated using data from GNSS base stations of GEONET, which is the Japanese GNSS network operated by the Geospatial Information Authority of Japan. The overall uncertainties of the point clouds, including scanning, regis- 


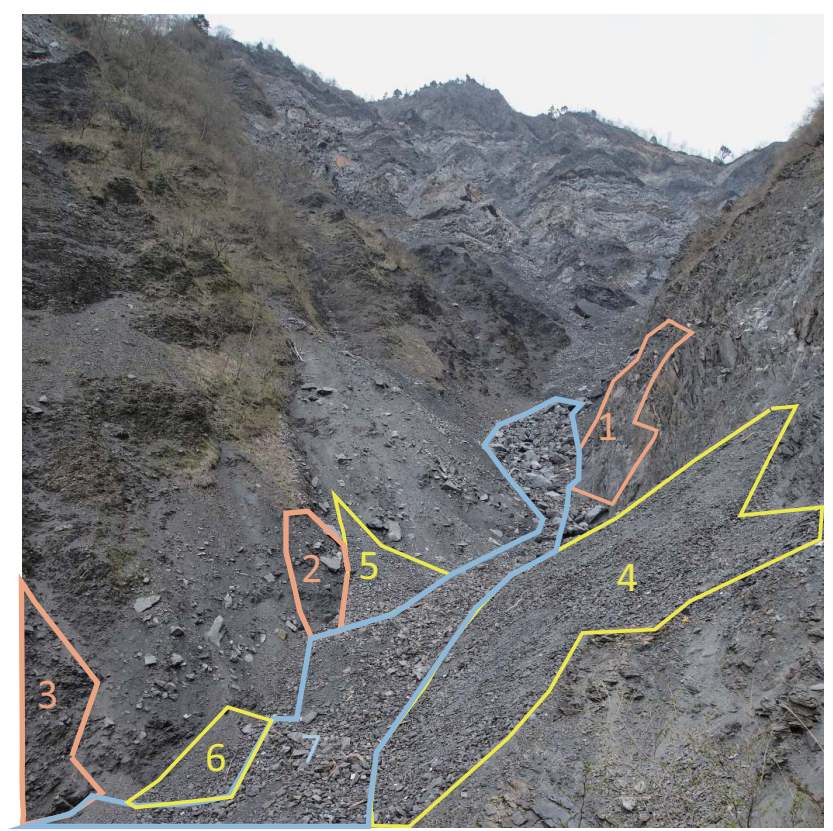

Figure 4. Photograph of the typical geomorphic units seen from P1. The image shows the area of rock slopes (surrounded by red lines), talus slopes (surrounded by yellow lines), and a channel (surrounded by blue lines) for which the slope gradient was calculated from DEMs with various grid sizes. The numbering of the area corresponds to that used in Fig. 7.

tration, and georeferencing by GNSS, were considered on the order of centimeters to a decimeter (Hayakawa et al., 2016).

After manually eliminating noise and unnecessary points, the point clouds obtained by the TLS measurement were converted into DEMs using a simple linear interpolation by triangulated irregular network and resampling, because vegetation cover was absent in the site. The resolution of the DEMs was set at $10 \mathrm{~cm}$, which sufficiently covers the average point density of the point clouds. Areas with sparse point clouds (approximately $<100 \mathrm{pts}^{-2}$ ), vegetated areas, and areas affected by the combination of various processes (e.g., talus slopes with the lower part eroded by stream flow) were excluded from the analyses.

The extent of typical geomorphic units in the TLS survey area, including three rock slopes, three talus slopes, and a channel around the monitoring plot P1, was mapped by field surveys (Fig. 4). Distribution of the slope gradient within these geomorphic units was calculated from TLS DEMs with various grid sizes. The mapping was conducted at the same time as each TLS survey because the area changed over time due to the sediment supply from outcrops and transportation of sediment by debris flows.

\subsection{Estimation of debris-flow volumes}

We estimated the volume of the storage by bedrock topography obtained by airborne laser scanning (ALS) and periodical photography (Imaizumi et al., 2016a). Thirty-three cross-sectional areas were calculated using the bedrock topography along the cross-sectional lines measured by the ALS in the periods when sediment storage was low (i.e., ALS in 2011 and 2012). The locations of the storage margins were interpreted using photographs taken periodically at sites P1 and P4 and assume that the surface topography of the storage is an inclined line that connects the differing elevations at the margins of the storage. The total volume of the storage was calculated by the sum of the cross-sectional area multiplied by the spacing of cross sections $(25 \mathrm{~m})$. The root mean squared error (RMSE) of the procedure, which was obtained from comparison of the volumes of storage by the procedure and by subtraction of ALS DEMs by estimated bedrock topography, was $5361 \mathrm{~m}^{3}$ (Imaizumi et al., 2016a). This RMSE is larger than the volume of small debris flows $\left(<2000 \mathrm{~m}^{3}\right)$ but below the sediment supply volume in each year $\left(>10000 \mathrm{~m}^{3}\right)$. This error may be similar or slightly larger than the errors in field surveys by Hungr et al. (2008), who estimated the volume of the eroded sediment to be $17 \%$ smaller than that of the deposited sediment.

\section{Results}

\subsection{Debris-flow monitoring}

From 1998 to 2015, 59 debris flows, which went through or terminated in the reach between the sites P1 and P3, were observed by video cameras, field surveys, and water pressure sensors in the upper Ichinosawa catchment. In addition, the occurrence of some other debris flows, which terminated above site P1, was found by periodic photography and field surveys. We analyzed video images of seven flows that were clearly captured by video cameras. In addition, photographs of one debris flow taken by TLCs with an interval of $1 \mathrm{~s}$ was analyzed (Table 2). We failed to obtain clear video images of other debris flows because of darkness at night and fog. The rainfall threshold for the occurrence of debris flow can be given by the $10 \mathrm{~min}$ rainfall intensity in the upper Ichinosawa catchment (Imaizumi et al., 2005). Comparison between duration of the rainfall event and the maximum $10 \mathrm{~min}$ rainfall intensity indicates that the rainfall threshold separating rainfall events with and without debris flows can be given by $5.0 \mathrm{~mm} 10 \mathrm{~min}^{-1}$ in the case of rainfall duration $\geq 10 \mathrm{~h}$ (Fig. 5). In the case of rainfall duration $<10 \mathrm{~h}$, the threshold can be obtained as a linear line in the double logarithmic plot (Fig. 5), as in other debris-flow torrents (Coe et al., 2008; Badoux et al., 2008; Theule et al., 2012). Most of the rainfall events triggering debris flows in the study site can be classified into two groups: long-lasting rainfall 
Table 2. Details of the rainfall and flow types examined using video camera and time-lapse camera (TLC) images during the debris-flow events analyzed in this study.

\begin{tabular}{|c|c|c|c|c|c|c|c|}
\hline Date & $\begin{array}{r}\text { Total rainfall } \\
(\mathrm{mm})\end{array}$ & $\begin{array}{l}\text { Maximum } 10 \mathrm{~min} \\
\text { rainfall intensity } \\
\left(\mathrm{mm} 10 \mathrm{~min}^{-1}\right)\end{array}$ & $\begin{array}{l}\text { Rainfall } \\
\text { duration }\end{array}$ & Rainfall type & $\begin{array}{l}\text { Type of } \\
\text { camera }\end{array}$ & $\begin{array}{l}\text { Location of } \\
\text { camera }\end{array}$ & $\begin{array}{l}\text { Proportional } \\
\text { duration of } \\
\text { partly saturated } \\
\text { flow in overall } \\
\text { debris-flow surges }\end{array}$ \\
\hline 30 August 2004 & 281.5 & 7.5 & $55 \mathrm{~h} 37 \mathrm{~min}$ & Typhoon & Video & P3 & $0.10^{\mathrm{a}}$ \\
\hline 19 July 2006 & 195.0 & 5.5 & $57 \mathrm{~h} 46 \mathrm{~min}$ & Stationary front & Video & $\mathrm{P} 2$ & 0.65 \\
\hline 6 September 2007 & 501.5 & 9.5 & 37 h $28 \mathrm{~min}$ & Typhoon & Video & $\mathrm{P} 2$ & $0.49^{\mathrm{a}}$ \\
\hline 5 August 2008 & 41.0 & 13.5 & $4 \mathrm{~h} 55 \mathrm{~min}$ & Convective & Video & $\mathrm{P} 2$ & 0.88 \\
\hline 24 July 2010 & 21.0 & 13.0 & $51 \mathrm{~min}$ & Convective & Video & $\mathrm{P} 2$ & 1.00 \\
\hline 30 September 2012 & 86.0 & 6.5 & 7 h 29 min & Typhoon & Video & $\mathrm{P} 3$ & $0.23^{\mathrm{a}}$ \\
\hline 6 August 2015 & 44.5 & 21.0 & $1 \mathrm{~h} 19 \mathrm{~min}$ & Convective & Video & $\mathrm{P} 1$ & 0.99 \\
\hline 9 September 2015 & 203.0 & 8.0 & $36 \mathrm{~h} 37 \mathrm{~min}$ & Typhoon & TLC & $\mathrm{P} 1$ & 0.42 \\
\hline
\end{tabular}

${ }^{\mathrm{a}}$ The latter half of the debris-flow event was not analyzed because of the darkness affected by the sunset. Therefore, the latter half of the event is not included in these data.

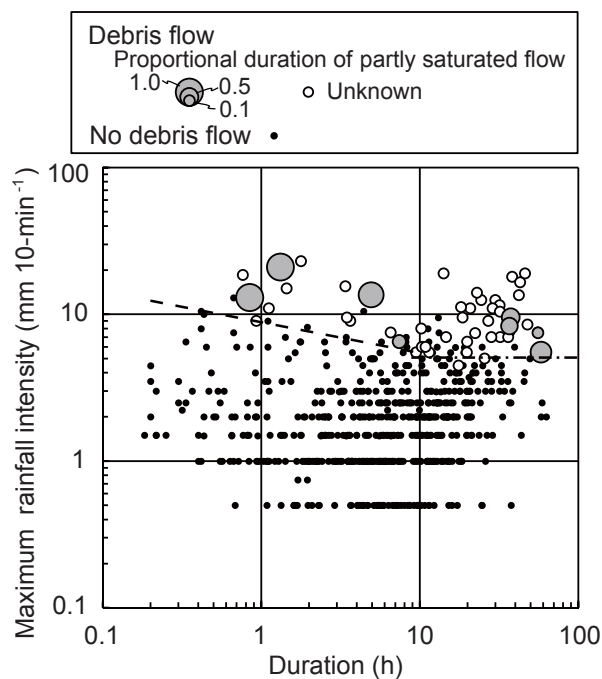

Figure 5. Comparison between rainfall duration and maximum 10 min rainfall intensity of rainfall events with total rainfall depth $>2.0 \mathrm{~mm}$ and rainfall duration $>10 \mathrm{~min}$ in the period from April 1998 to September 2015. Rainfall events with and without debris flows were potted using different markers. The size of the plot for debris-flow events expresses proportional duration of partly saturated flow in overall debris-flow surges. The rainfall intensity was calculated from rainfall data with a logging interval of 1 min. Rainfall events without $1 \mathrm{~min}$ interval data were not plotted. The dashed line, which can be expressed as intensity $=8.86$ (duration $)^{-0.21}$, indicates a lower limit of the rainfall condition needed for occurrence of debris flows when rainfall duration is $<10 \mathrm{~h}$. The Dash-dot line indicates the maximum rainfall intensity equals $5 \mathrm{~mm}$ per $10 \mathrm{~min}$, which is the rainfall threshold for occurrence of debris flow when the rainfall duration is $\geq 10 \mathrm{~h}$. Proportional duration of the partly saturated flow could not be calculated during "unknown" debrisflow events because of absent of continuous debris-flow images due to mechanical problems of the monitoring system, darkness at night, and fog.
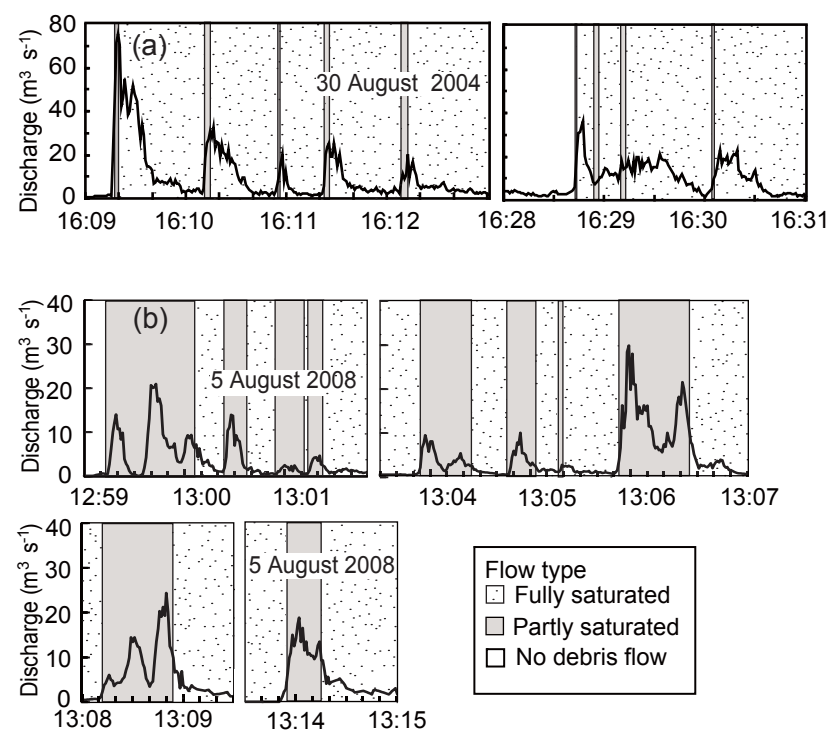

Figure 6. Hydrograph and the duration of each flow type during debris-flow events. (a) Debris flow monitored at P3 on August 30, 2004, mainly consisting of fully saturated flow. (b) Debris flow monitored at P2 on 5 August 2008, mainly consisting of partly saturated flow.

events with a high value of total rainfall depth, caused by typhoons and stationary fronts (rainfall duration $>5 \mathrm{~h}$ and total rainfall depth $>50 \mathrm{~mm}$ ), and short-duration convective rainfall events characterized by high intensity (rainfall duration $<5 \mathrm{~h}$, total rainfall depth $<50 \mathrm{~mm}$; Table 2 ).

Debris-flow hydrographs obtained from video images show that debris flows are composed of many surges with duration of $20 \mathrm{~s}$ to $1 \mathrm{~min}$ (Fig. 6). As noted above, two types of flow have been observed in the Ohya landslide: flow mainly composed of cobbles and boulders (partly saturated flow) and flow mainly composed of muddy water (fully saturated flow). The duration of each flow phase varied between the events. 


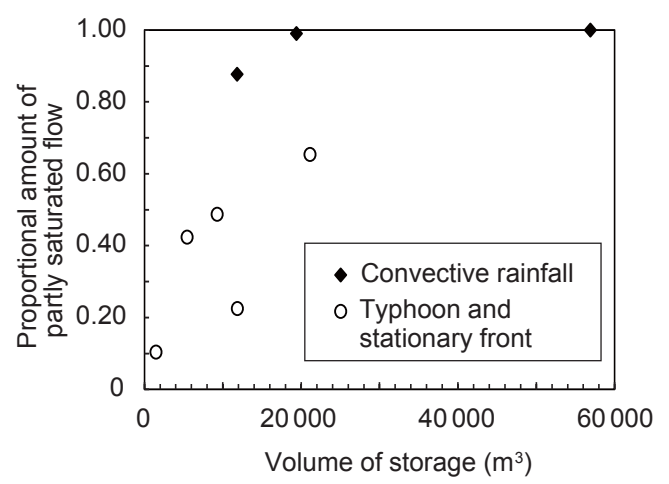

Figure 7. Comparison between the volume of storage and the duration of partly saturated flow as a proportion of the overall debrisflow surges. Rainfall duration and total rainfall depth of the convective rainfall are $<5 \mathrm{~h}$ and $<50 \mathrm{~mm}$, respectively, while those of typhoon and stationary fronts are $>5 \mathrm{~h}$ and $>50 \mathrm{~mm}$, respectively.

For example in the event of 5 August 2008, $88 \%$ of debrisflow surges (percentage respect to the total event duration) was composed of partly saturated flow, while, in the event of 30 August 2004 (Fig. 6), $90 \%$ in time of the phenomenon was composed of fully saturated flow. The proportional duration of the partly saturated debris flow in overall debris-flow surges was generally high during convective rainfall events with high rainfall intensity and short rainfall duration (Fig. 5, Table 2). The proportional duration of the partly saturated debris flow also had a weak positive relationship with the volume of storage estimated from periodical photography $\left(R^{2}=0.37, p\right.$ value $=0.06$; Fig. 7$)$.

\subsection{Slope gradient of geomorphic units}

Mapping of the three geomorphic units (rock slopes, talus slopes, and the channel) in the TLS survey area showed that the size of each unit changed with time due to sediment supply and transport processes. Slope gradient was calculated using a $3 \times 3$ neighborhood around each cell in the DEM with various grid sizes obtained by TLS (Horn, 1981; Fig. 8). Average and standard deviation of slope gradient in the three geomorphic units (rock slopes, talus slopes, and the channel) throughout the TLS monitoring period were calculated from DEMs with various grid size. As reported by previous studies (Loye et al., 2009), the average slope gradient of each geomorphic unit becomes gentler with an increase in the grid size, because small-scale asperities of terrains (e.g., boulders) are smoothed when the grid size is larger (Fig. 9a). However, the relationship between the grid size and slope gradient was slightly different among geomorphic units. For a grid size of $\geq 1.0 \mathrm{~m}$, a histogram of the slope gradient in talus slopes was concentrated in a narrow range around the average value (i.e., $>60 \%$ in the range between 34 and $40^{\circ}$ for a grid size of $5.0 \mathrm{~m}$; Fig. 9b). This slope angle is considered to represent $\alpha_{1}$, as reported in previous studies (Kirkby and Statham, 1975; Carson, 1977; Obanawa and Matsukura, 2008; Loye et al., 2009). The standard deviation of the slope gradient in the rock slope decreased with an increase in grid size when the grid size was smaller than the width of alternative strata in the study area (about $4.0 \mathrm{~m}$; Imaizumi et al., 2015), and it was almost constant when the grid size was larger than that. The standard deviation of the slope gradient in the channel also decreased with an increase in grid size when the grid size was smaller than $4.0 \mathrm{~m}$, and it was almost constant when the grid size was larger than $4.0 \mathrm{~m}$. This inflection point of the trend $(4.0 \mathrm{~m})$ was larger than the largest boulder size in the channel, changing with time from 1 to $2 \mathrm{~m}$ (Imaizumi et al., 2006, 2016c).

\subsection{Longitudinal channel topography}

Longitudinal channel profiles obtained by the post-event surveys were analyzed by GIS to find out the relationship between the debris-flow type and channel gradient formed by the debris flow in the steep debris-flow initiation zone (Fig. 10). The longitudinal channel profile between points A and G (total length of $100 \mathrm{~m}$; Fig. 2) on 21 November 2012 was mainly formed by a debris flow on 30 September 2012, which was dominated by fully saturated flow. In contrast, the channel topography on 23 August 2015 was mainly formed by a debris flow on 6 August 2015, which was dominated by partly saturated flow. A small debris flow on $17 \mathrm{Au}-$ gust 2015, which transported storage with a volume of $<$ $3000 \mathrm{~m}^{3}$, also affected a part of the channel topography measured on 23 August 2015; however, the affected area was limited (mostly a width of $<5 \mathrm{~m}$ ) because of its small discharge. Thus, we assumed that the longitudinal channel profile in the survey section on 23 August 2015 reflected characteristics of the debris flow on 6 August 2015 rather than that on 17 August 2015. Channel bed deformations over several meters, which were caused by sediment supply from hillslopes and erosion and deposition of sediment by debris flows, have been observed by the periodical TLS survey in the lowermost and uppermost reaches (from point $\mathrm{A}$ to $\mathrm{B}$ and from point $\mathrm{E}$ to F, respectively) (Hayakawa et al., 2016). In contrast, such channel bed deformations have not been observed in the middle reaches (from point $C$ to $D$ ).

When we compared longitudinal channel profiles on 21 November 2012 and 23 August 2015, the channel bed level was clearly different ( $>3 \mathrm{~m}$ in depth) at the lowermost and uppermost reaches (from point $\mathrm{A}$ to $\mathrm{B}$ and from point $\mathrm{E}$ to $\mathrm{F}$, respectively). In contrast, there was almost no change in the longitudinal channel profile $(<1 \mathrm{~m})$ in the middle reaches. Regardless of the section length for analysis, the distribution of the channel gradient calculated on 21 November 2012 (mainly formed by fully saturated flow) was clearly wider than that on 23 August 2015 (mainly formed by partly saturated flow; Fig. 10b, c, d; Table 3a). The $p$ value obtained by an $F$ test of the difference in the dispersion of the channel gradient between the two periods was $<0.001,<0.001$, 

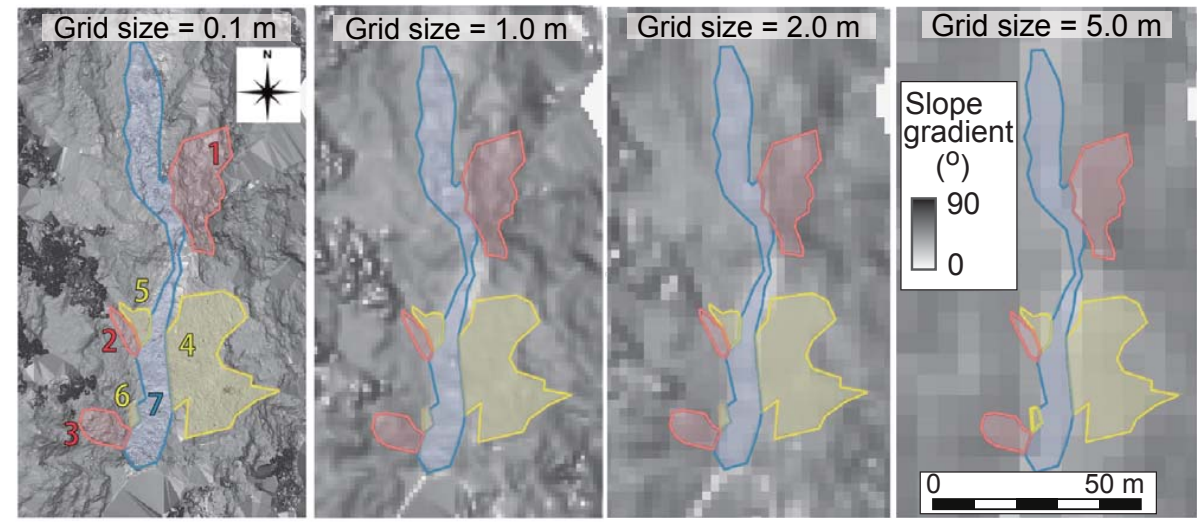

Figure 8. Slope gradient map calculated after using terrestrial laser scanning (TLS) data on 14 May 2014, with various grid sizes. The location of the analysis area is shown in Fig. 2. Areas colored red, yellow, and blue indicate rock slopes, talus slopes, and a channel, respectively.

(a) Average slope gradient

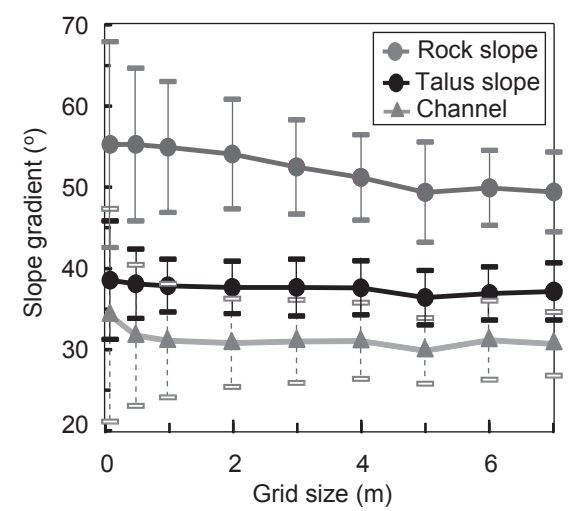

(b) Histogram

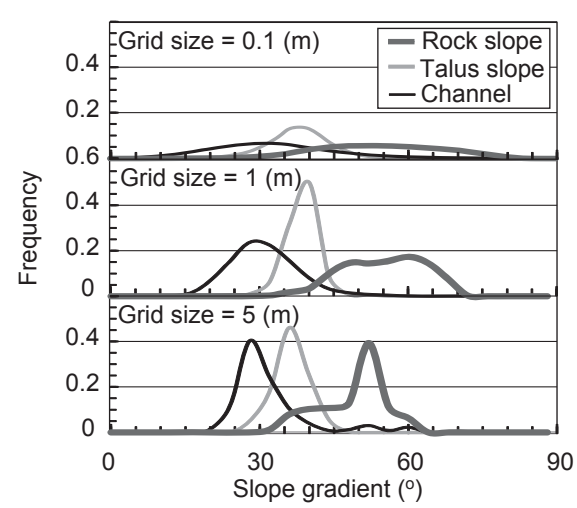

Figure 9. Slope gradient of typical geomorphic units calculated from terrestrial laser scanning (TLS)-derived digital elevation maps (DEMs) with various grid sizes. Topographic data in all measurement periods were used in the statistical analysis. (a) Changes in the average slope gradient of each geomorphic unit with an increase in the grid size. The slope gradients in all periods were averaged. The bars attached to the plots indicate the range of the standard deviation. (b) Histogram of the slope gradient calculated from TLS DEMs, with grid sizes of 0.1, 1.0, and $5.0 \mathrm{~m}$. Integrals of the frequency for each geomorphic unit in Fig. 8b, which are categorized with $2^{\circ}$ step, are all 1.

and 0.065 for each $0.1,1.0$, and $5.0 \mathrm{~m}$ section, respectively. Wide distribution of the slope gradient for each $5.0 \mathrm{~m} \mathrm{sec}-$ tion on 21 November 2012 was mainly attributed to the steppool topography formed by large boulders and the bedrock step pool, while that for each $1.0 \mathrm{~m}$ section was attributed to small-scale topographies together with the particle size of large boulders.

Such temporal changes in the channel gradient were more evident in the sections with clear changes in the channel bed topography (from point $\mathrm{A}$ to $\mathrm{B}$ and from point $\mathrm{E}$ to F) compared to those without clear changes in the channel bed topography (from point $\mathrm{B}$ to $\mathrm{E}$ and from point $\mathrm{F}$ to $\mathrm{G}$ ) (Table $3 b, c)$. The cross-sectional topography in the reaches without active channel bed deformation was narrowed by the massive and steep rock cliffs at the left bank. High stream power attributed to the high flow depth in this section possibly restricted accumulation of the storage, resulting in in- active changes in the channel bed topography. The standard deviation of the channel gradient in the active channel bed deformation sections had a negative relationship with the volume of the storage (Fig. 11a). The $p$ values for the linear regressions with section lengths of $0.1,1.0$, and $5.0 \mathrm{~m}$ were $0.099,0.026$, and 0.021 , respectively. The average slope gradient in the section between $\mathrm{A}$ and $\mathrm{E}$ was not significantly different between the two periods ( 23.1 and $25.4^{\circ}$ for 21 November 2012 and 23 August 2015, respectively).

Periodic photography and field surveys after eight debris flows, which were successfully monitored by video cameras and TLCs, indicated that small-scale topography after debris flows mainly consisting of fully saturated flow are rugged compared to that after debris flows mainly consisting of partly saturated flow. This trend agrees with that observed by TLS surveys (Fig. 10, Table 3a). 
Table 3. Standard deviation of the channel gradient and proportional amount of channel sections in which the gradient was in the range between $\alpha_{2}$ and $\alpha_{1}$ throughout the entire channel section.

(a) Entire channel section between points A and G

\begin{tabular}{lrrrrrrr}
\hline Measurement date & \multicolumn{2}{c}{ Standard deviation of the channel gradient $\left(^{\circ}\right)$} & & \multicolumn{2}{c}{ Proportion of all sections between $\alpha_{1}$ and $\alpha_{2}$} \\
\cline { 2 - 3 } & $0.1 \mathrm{~m}$ interval & $1.0 \mathrm{~m}$ interval & $5.0 \mathrm{~m}$ interval & & $0.1 \mathrm{~m}$ interval & $1.0 \mathrm{~m}$ interval & $5.0 \mathrm{~m}$ interval \\
\hline 21 November 2012 & 23.7 & 10.3 & 5.8 & & 0.31 & 0.52 & 0.80 \\
23 August 2015 & 18.7 & 7.0 & 3.7 & & 0.38 & 0.73 & 0.95 \\
\hline
\end{tabular}

(b) Sections with active channel bed deformation (from point A to $\mathrm{B}$ and from point $\mathrm{E}$ to $\mathrm{F}$ )

\begin{tabular}{lrrrrrrr}
\hline Measurement date & \multicolumn{2}{c}{ Standard deviation of the channel gradient $\left(^{\circ}\right)$} & & \multicolumn{2}{c}{ Proportion of all sections between $\alpha_{1}$ and $\alpha_{2}$} \\
\cline { 2 - 3 } & $0.1 \mathrm{~m}$ interval & $1.0 \mathrm{~m}$ interval & $5.0 \mathrm{~m}$ interval & & $0.1 \mathrm{~m}$ interval & $1.0 \mathrm{~m}$ interval & $5.0 \mathrm{~m}$ interval \\
\hline 21 November 2012 & 27.0 & 11.4 & 6.3 & & 0.30 & 0.38 & 0.44 \\
23 August 2015 & 17.9 & 7.2 & 3.4 & & 0.48 & 0.71 & 0.89 \\
\hline
\end{tabular}

(c) Sections without active channel bed deformation (from point $\mathrm{B}$ to $\mathrm{E}$ and from point $\mathrm{F}$ to $\mathrm{G}$ )

\begin{tabular}{lrrrrrrr}
\hline Measurement date & \multicolumn{2}{c}{ Standard deviation of the channel gradient $\left(^{\circ}\right)$} & & \multicolumn{2}{c}{ Proportion of all sections between $\alpha_{1}$ and $\alpha_{2}$} \\
\cline { 2 - 3 } & $0.1 \mathrm{~m}$ interval & $1.0 \mathrm{~m}$ interval & $5.0 \mathrm{~m}$ interval & & $0.1 \mathrm{~m}$ interval & $1.0 \mathrm{~m}$ interval & $5.0 \mathrm{~m}$ interval \\
\hline 21 November 2012 & 20.9 & 8.6 & 5.1 & & 0.34 & 0.61 & 0.90 \\
23 August 2015 & 18.8 & 6.5 & 3.5 & & 0.33 & 0.76 & 1.00 \\
\hline
\end{tabular}

As noted above, the theoretical channel gradient dividing partly and fully saturated debris flows $\left(\alpha_{2}\right)$ can be obtained from Eq. (5). Because the dispersion of boulders in the partly saturated debris flows was not evident in video images, porosity (ratio of liquid and vapor phases, to be exact) in the partly saturated flow may not be higher than that in the saturated channel deposits. By assuming $\phi=37.3^{\circ}$ (average slope gradient of the talus slope for a grid size $=1.0$ to $7.0 \mathrm{~m}$ ), $n=0.3$ (same as the porosity of channel deposits), $\gamma_{\mathrm{s}}=26000$, and $\gamma_{\mathrm{w}}=9800$, the $\alpha_{2}$ in the Ohya landslide was $22.2^{\circ}$. In order test whether Eq. (3) is applicable to the monitoring result, the proportional amount of channel sections in which the gradient ranged between $\alpha_{2}$ and $\alpha_{1}$ (theoretical channel gradient for partly saturated flow) throughout the active channel deformation sections (total $40 \mathrm{~m}$ ) was calculated (Table 3b, Fig. 11b). Based on Eq. (4), we approximate $\phi\left(37.3^{\circ}\right)$ as $\alpha_{1}$ (theoretical slope gradient dividing fully unsaturated and partly saturated sediment transports). The proportional amount of channel sections between $\alpha_{2}$ and $\alpha_{1}$ on 23 August 2015 (after being mainly formed by partly saturated flow) was higher than on 21 November 2012 (after being mainly formed by fully saturated flow) regardless of the interval of the channel section for the analyses (Table $3 \mathrm{~b}$ ). The proportional amount of channel sections between $\alpha_{2}$ and $\alpha_{1}$ was higher when the volume of storage was large (Fig. 11b). In contrast, the proportional amount of channel sections gentler than $\alpha_{2}$ (theoretical channel gradient for fully saturated flow) decreased with an increase in the volume of sediment storage.

\section{Discussion}

\subsection{Factors controlling the debris-flow type}

In contrast to debris-flow transportation zones in other torrents, in which partly saturated flow dominates just at the front of the surges (McArdell et al., 2007; McCoy et al., 2010; Okano et al., 2012), our observations in the debris-flow initiation zone of the upper Ichinosawa showed that debrisflow surges were sometimes mainly composed of partly saturated flow (Table 2). Many sections in the upper Ichinosawa catchment are greater than $22.2^{\circ}$ (Fig. 10), which is the theoretical channel gradient needed for occurrence of a partly saturated debris flow $\left(\alpha_{2}\right)$ in the Ichinosawa catchment. Similarly, debris-flow initiation zones in many other torrents are greater than $22.2^{\circ}$ (e.g., VanDine, 1985; McCoy et al., 2012). Although the $\alpha_{2}$ may be different among torrents affected by soil parameters such as the internal angle of friction, the conditions for the occurrence of partly saturated flow may possibly be satisfied in such debris-flow initiation zones.

The proportional duration of partly saturated flow in the overall surges had a weak positive relationship with the volume of storage (Fig. 7). Effects of the storage volume on the debris-flow type were also implied based on the field monitoring in Cancia, Italy (Gregoretti et al., 2016). It indicates that the volume of storage was a factor controlling not only the initiation of the debris flow, particularly in the supplylimited basin (Bovis and Jakob, 1999; Jakob et al., 2005), but also the debris-flow characteristics. The water content in the storage, which is considered an important factor controlling flow characteristics (Takahashi, 1991; Hürlimann et al., 


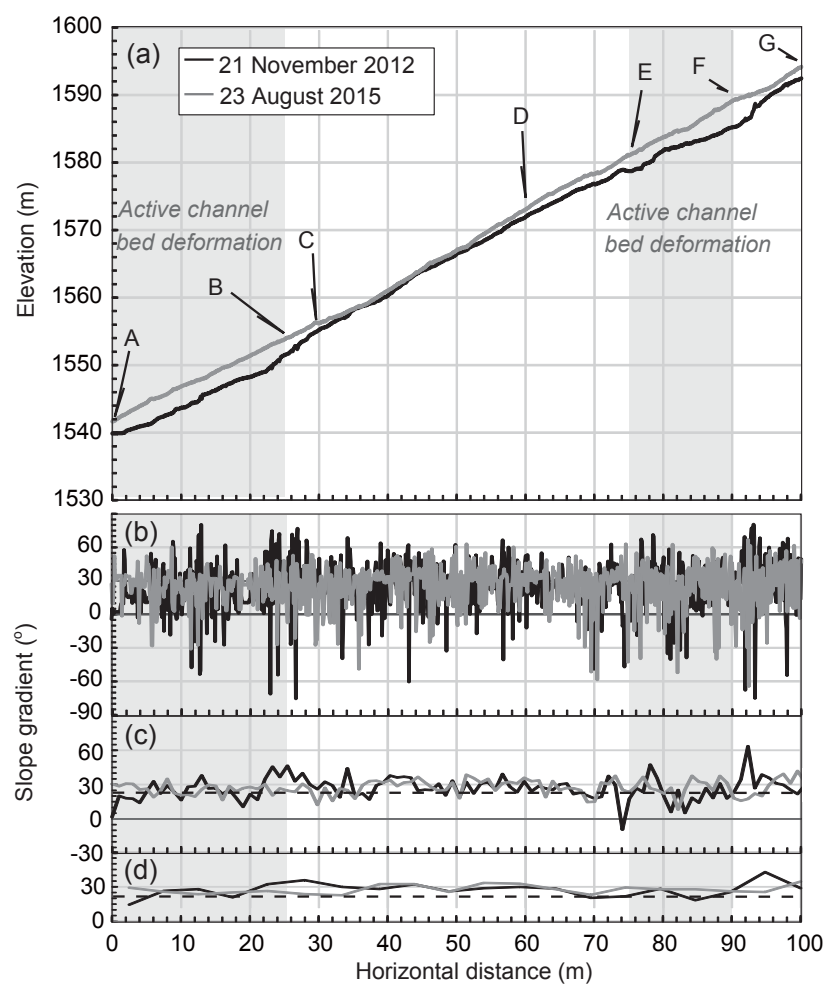

Figure 10. Longitudinal channel profiles and the channel gradient mainly formed by fully saturated flow (measured on 21 November 2012 after the debris flow on 30 September 2012) and partly saturated flow (measured on 23 August 2015 after the debris flow on 6 August 2015) obtained from $0.1 \mathrm{~m}$ terrestrial laser scanning (TLS)-derived digital elevation maps (DEMs). (a) Longitudinal channel profile in the section between A and E in Fig. 2. (b) Longitudinal changes in the channel gradient calculated for each section with a length of $0.1 \mathrm{~m}$. (c) Longitudinal changes in the channel gradient calculated for each section with a length of $1.0 \mathrm{~m}$. (d) Longitudinal changes in the channel gradient calculated for each section with a length of $5.0 \mathrm{~m}$.

2015), may affect such relationships. When a large volume of storage is present in a basin, a large amount of water is needed for saturation of the storage, which can be difficult to attain. In such cases, even if the sediment mass that initially moved in the channel were saturated, storage along the channel eroded by the debris flow would not be fully saturated when the channel gradient $>\alpha_{2}$. Consequently, partly saturated flow can easily dominate when a large volume of storage accumulates in the channel. Such erosion of unsaturated sediment has also been reported in other channels (Berger et al., 2011b; McCoy et al., 2012). In contrast, storage can be easily saturated by smaller amounts of rainfall when there is only a small volume of storage in the basin. In such cases, even when debris flows were not fully saturated in their initial stages, as they traveled downstream they possibly became saturated by the water supply from tributaries as well as the erosion of saturated deposits.
Our monitoring results also revealed that the proportional duration of partly saturated flow in a debris-flow event was low during long-lasting rainfall events (e.g., typhoons and stationary fronts), while the duration was high during shortlasting rainfall events (e.g., convective rainfall; Table 2, Fig. 5). The relationships between rainfall patterns and flow types have also been reported in other debris-flow basins (Okano et al., 2012; Kean et al., 2013; Hürlimann et al., 2014). Okano et al. (2012) reported that the front of a surge in the transportation zone was completely saturated when rainfall intensity over a long duration $(24 \mathrm{~h})$ was high, while partly saturated flow occurred at the front of the surges during short-term, intense rainfall events. Such rainfall patterns may relate debris-flow type by affecting water contents in the storage together with the volume of storage. Previous study reported changes in the flow characteristics during a debris-flow event associated with the sediment supply from hillslopes (Staley et al., 2014; Zhou et al., 2015), possibly because of the increase in the amount of sediment relative to the water in channels.

\subsection{Influence of the sediment transport type on the slope gradient of terrains}

The values of topographic indexes (e.g., slope gradient) are variable depending on the scale of the window size used in the GIS analyses, because factors affecting the indexes are different among the scales of topography (Schmidt and Andrew, 2005; Loye et al., 2009; Pirotti and Tarolli, 2010; Drăguţ and Eisank, 2011). The histogram for the talus slope was steep when grid size was $\geq 1.0 \mathrm{~m}$, which was larger than the maximum grain size of boulders on talus slopes $(0.5 \mathrm{~m}$, Fig. 9). The histogram for the channel with grid size of $5.0 \mathrm{~m}$ was steeper and higher than that with grid size of $1.0 \mathrm{~m}$, possibly affected by the size of the largest boulders in the channel, changing from 1 to $2 \mathrm{~m}$, associated with the sediment supply from hillslopes and sediment transport by debris flows (Imaizumi et al., 2006, 2016c). Thus, when we analyze the relationship between the type of sediment transport and the slope gradient of terrains, window sizes larger than the particle size, which can eliminate roughness attributed to the particle size, would be appropriate, because the particle size is considered to not be directly affected by the sediment transport type.

A large part of the histogram of the rock slopes was steeper than $40^{\circ}$ for a grid size of $>4.0 \mathrm{~m}$ (e.g., $80 \%$ of the slopegradient histogram for a grid size of $5.0 \mathrm{~m}$; Fig. 9b), indicating that fully unsaturated sediment transport, which occurs on slopes steeper than $\alpha_{1}$ (Eq. 4), is dominant on rock slopes. In contrast, most of the channel was gentler than $\alpha_{1}$ for a grid size of $>4.0 \mathrm{~m}$ (e.g., $>85 \%$ of the slope-gradient histogram for a grid size of $5.0 \mathrm{~m}$; Fig. 9b), indicating that fully and partly saturated debris flows are dominant in the channel. Such a trend was also apparent in the longitudinal channel profile of the channel (Fig. 10b). Based on the statis- 
(a)

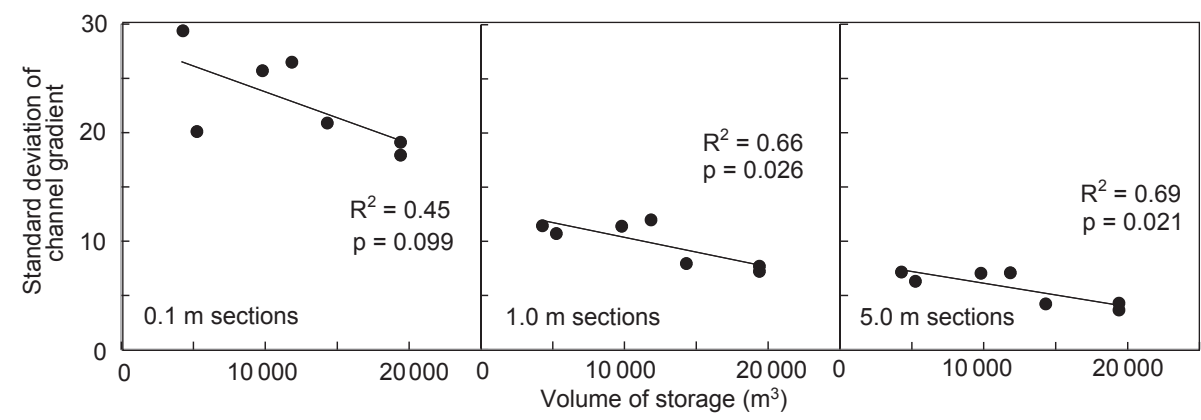

(b)

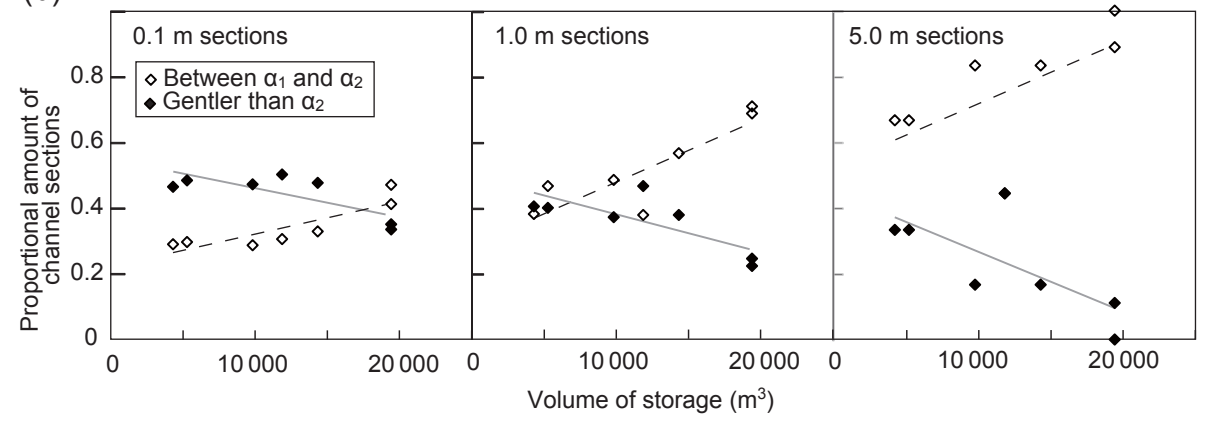

Figure 11. Comparison between the volume of storage and channel topography. (a) Comparison of the volume of storage with the standard deviation of the channel gradient for each $0.1,1.0$, and $5.0 \mathrm{~m}$ section in the active channel bed deformation zones (from point A to B and from point $\mathrm{E}$ to F). (b) Comparison of the volume of storage with the proportional amount of the channel sections in which the channel gradient ranged between $\alpha_{1}$ and $\alpha_{2}$ (theoretical channel gradient for partly saturated debris flow) and was gentler than $\alpha_{2}$ (theoretical channel gradient for fully saturated debris flow) in the active channel bed deformation zones. Topographic data before the first debris flow in each year were excluded from the analyses, because the channel gradient was possibly affected by the sediment supply from hillslopes, as well as the last debris flow of the previous year. The topography on 17 August 2014 was also excluded from the analysis because we failed to measure topography by terrestrial laser scanning (TLS) in the upper part of the active channel bed deformation zones because of fog. Linear regression lines for each relationship are also shown in the figure.

\begin{tabular}{l|ll} 
Volume of storage & \multicolumn{1}{|c}{ Large } & $\begin{array}{l}\text { Small } \\
\text { Fainly composed of } \\
\text { partly saturated flow }\end{array}$ \\
\hline $\begin{array}{l}\text { Channel } \\
\text { topography }\end{array}$ & Bully saturated flow
\end{tabular}

Figure 12. Schematic diagram of the relationships between the volume of storage, flow type, and channel topography. $\alpha$ is the channel gradient, $\alpha_{1}$ is the theoretical boundary of the channel gradient between fully unsaturated and partly saturated sediment transport, and $\alpha_{2}$ is the theoretical boundary of the channel gradient between partly and fully saturated sediment transport.

tics of the channel gradient for each $5.0 \mathrm{~m}$ channel section, the proportional amount of channel sections in which the gradient was in the theoretical range of fully and partly saturated flows was almost 1.0 (Fig. 11).
The longitudinal channel gradient changed with time and was affected by the predominant type of flow during the preceding debris-flow events (Fig. 10). The proportional amount of channel sections between $\alpha_{1}$ and $\alpha_{2}$ (theoretical range of the channel gradient for partly saturated debris flow) among all active channel deformation sections was higher when a larger volume of storage was present in the catchment (Fig. 11b). Because partly saturated flow dominated when a large volume of storage was present in the catchment (Fig. 7), partly saturated debris flow likely formed channel topographies with a theoretical channel gradient for the partly saturated flow (Fig. 12). Similarly, the length of the channel sections in the theoretical range for fully saturated flow $\left(<\alpha_{2}\right)$ was high when small amounts of storage accumulated in the channel (Fig. 11b) during periods when fully saturated flow dominated (Fig. 7). Thus, fully saturated flow tended to form channel sections gentler than $\alpha_{2}$ (Fig. 12). The standard deviation of the channel gradient after a debris flow mainly consisting of fully saturated flow was higher than that after a debris flow mainly consisting of partly saturated flow (Fig. 9, Table 3). In addition, the standard deviation of the 
channel gradient was high when small volumes of storage accumulated in the basin (Fig. 11a), implying that fully saturated flow tended to form a step-pool topography. As a result of field surveys and periodic topography, step-pool topography formed by large boulders and the bedrock was generally seen after fully saturated flows. Since temporal changes in the channel gradient were not apparent in the larger-scale topography (i.e., channel gradient for entire sections with an active channel bed deformation), the decrease in the channel gradient due to fully saturated flow does not likely occur throughout the channel but was occasionally interrupted by steep sections formed by large boulders and bed rock, which cannot be eroded easily (Fig. 12).

Because we did not consider the dynamic mechanisms of the debris flow, including the collision of particles and the dynamic pressure of interstitial water (Coussot and Meunier, 1996; Takahashi, 2014), our analysis could not discuss the unsteady nature of debris flows, such as temporal changes in the flow type during a debris-flow event. In addition, the temporary appearance of the unsaturated (or extremely dense) debris flows in gentler torrents does not agree with our analysis of static force (McArdell et al., 2007; McCoy et al., 2013; Okano et al., 2012). The depth profile of the dynamic force affected by the slope gradient and the particle size relative to the flow depth should be considered to complete the explanation of such dense debris flows (Takahashi, 2007; Lanzoni et al., 2017). Nevertheless, our analysis results suggested that rough relationships between the predominant types of sediment transport and the slope gradient could exist in the debris-flow initiation zone.

\section{Summary and conclusion}

We investigated the relationship between the flow type (partly and fully saturated flows) and accumulation conditions of sediment storage (i.e., channel gradient and volume of storage) in the debris-flow initiation zone at the Ohya landslide, Japan, using various methods, including a physical analysis of static force, field monitoring, periodical TLS surveys, and an estimation of the volume of storage using GIS. Our study revealed that both partly and fully saturated debris flows are important hydrogeomorphic processes in the initiation zone because of the steep terrain. The predominant type of flow is affected by the volume of storage as well as rainfall patterns, which control the amount of water in the storage. For example, fully saturated flow dominated when the total volume of storage was $<10000 \mathrm{~m}^{3}$, while partly saturated flow dominated when the total volume of the storage was $>15000 \mathrm{~m}^{3}$. In addition, small-scale channel gradients (on the order of meters) formed by erosion and deposition reflected the dominant flow type in the debris-flow events. A large part of the channel sections after partly saturated debris flows were steeper than $22.2^{\circ}$, while fully saturated debris flows tended to form channel sections gentler than $22.2^{\circ}$.
Such relationship between the flow type and channel gradient could be explained by a simple analysis of static force at the bottom of the sediment mass.

Our study implies that the volume of storage and the rainfall patterns, which control predominant debris-flow type classified by the ratio of the depth of the saturated zone, provide useful information to improve the debris-flow warning system, since the flow characteristics (e.g., sediment concentration, velocity) are different among debris-flow types. In addition, our study elucidated that the slope gradient of geomorphic units (i.e., talus slopes and channel deposits) is the key factor in the estimation of the predominant type of the sediment transport processes in the Ohya landslide, where stony debris flows occur due to the mobilization of storage laid on the steep channel. Therefore, periodical measurement of the topography in debris-flow initiation zones is considered to be essential for better risk assessment of debris-flow hazards. Because the initiation mechanism of the debris flow and the important force inside of the flow (e.g., frictional force, grain collision) vary and are affected by the site conditions (e.g., grain size of material, slope gradient), monitoring data in other debris-flow torrents are needed for the further understanding of the relationship between the debrisflow type and the accumulation conditions of the storage.

Data availability. The data used in this paper can be requested from the corresponding author.

Competing interests. The authors declare that they have no conflict of interest.

Acknowledgements. This study was supported by JSPS grant numbers 25702014, 26292077, and 26282076. The airborne DEM was provided by the Shizuoka River Office, Chubu Regional Bureau, Ministry of Land, Infrastructure, Transport and Tourism, Japan. We thank Hitoshi Saito for his comments which improved the structure of the manuscript. We are grateful to Carlo Gregoretti, Michel Jaboyedoff, and an anonymous reviewer, who provided critical reviews that improved our paper. Editor Paolo Tarolli is thanked for his efforts in handling the manuscript.

Edited by: Paolo Tarolli

Reviewed by: Carlo Gregoretti, Michel Jaboyedoff, and one anonymous referee

\section{References}

Arattano, M.: On the use of seismic detectors as monitoring and warning system for debris flows, Nat. Hazards, 20, 197-213, 1999.

Arattano, M., Marchi, L., and Cavalli, M.: Analysis of debrisflow recordings in an instrumented basin: confirmations and 
new findings, Nat. Hazards Earth Syst. Sci., 12, 679-686, https://doi.org/10.5194/nhess-12-679-2012, 2012.

Badoux, A., Graf, C., Ryhner, J., Kuntner, R., and McArdell, B. W.: A debris-flow alarm system for the Alpine Illgraben catchment: design and performance, Nat. Hazards, 49, 517-539, 2008.

Berger, C., McArdell, B. W., and Schlunegger, F.: Sediment transfer patterns at the Illgraben catchment, Switzerland: Implications for the time scales of debris flow activities, Geomorphology, 125, 421-432, 2011a.

Berger, C., McArdell, B. W., and Schlunegger, F.: Direct measurement of channel erosion by debris flows, Illgraben, Switzerland. J. Geophys. Res., 116, F01002, https://doi.org/10.1029/2010JF001722, 2011b.

Berti, M., Genevois, R., Simoni, A., and Tecca, P. R.: Field observations of a debris flow event in the Dolomites, Geomorphology, 29, 265-274, 1999.

Bovis, M. J. and Jakob, M.: The roll of debris supply conditions in predicting debris flow activity, Earth Surf. Process. Landf., 24, 1039-1054, 1999.

Carson, M. A.: Angle of repose, angle of shearing resistance and angle of talus slopes, Earth Surf. Process., 2, 368-380, 1977.

Chen, H. X., Zhang, L. M., Chang, D. S., and Zhang, S.: Mechanisms and runout characteristics of the rainfall triggered debris flow in Xiaojiagou in Sichuan Province, China, Nat. Hazards, 62, 1037-1057, 2012.

Coe, J. A., Kinner, D. A., and Godt, J. W.: Initiation conditions for debris flows generated by runoff at Chalk Cliffs, central Colorado, Geomorphology, 96, 270-297, 2008.

Coussot, P. and Meunier, M.: Recognition, classification and mechanical description of debris flows, Earth-Sci. Rev., 40, 209227, 1996

Cui, P., Hu, K., Zhuang, J., Yang, Y., and Zhang, J.: Prediction of debris-flow danger area by combining hydrological and inundation simulation methods, J. Moun. Sci., 8, 1-9, https://doi.org/10.1007/s11629-011-2040-8, 2011.

Degetto, M., Gregoretti, C., and Bernard, M.: Comparative analysis of the differences between using LiDAR contourbased DEMs for hydrological modeling of runoff generating debris flows in the Dolomites, Front. Earth Sci., 3, 21, https://doi.org/10.3389/feart.2015.00021, 2015.

Dorren, L. K. A.: A review of rockfall mechanics and modelling approaches, Prog. Phys. Geogr., 27, 69-87, 2003.

Drăguţ, L. and Eisank, C.: Object representations at multiple scales from digital elevation models, Geomorphology, 129, 183-189, 2011.

Egashira, S., Itoh, T., and Takeuchi, H.: Transition mechanism of debris flows over rigid bed to over erodible bed, Phys. Chem. Earth, Part B: Hydrology, Oceans and Atmosphere, 26, 169-174, https://doi.org/10.1016/S1464-1909(00)00235-5, 2001.

Gabet, E. J.: Sediment transport by dry ravel, J. Geophys. Res., 108, 2049, https://doi.org/10.1029/2001JB001686, 2003.

Gregoretti, C.: Inception sediment transport relationships at high slopes, J. Hydraul. Eng., 134, 1620-1629, 2008.

Gregoretti, C. and Dalla Fontana, D.: The triggering of debris flow due to channel-bed failure in some alpine headwater basins of the Dolomites: analyses of critical runoff, Hydrol. Process., 22, 2248-2263, https://doi.org/10.1002/hyp.6821, 2008.

Gregoretti, C., Degetto, M., Bernard, M., Crucil, G., Pimazzoni, A., De Vido, G., Berti, M., Simoni, A., and Lanzoni, S.: Runoff of small rocky headwater catchments: Field observations and hydrological modeling, Water Resour. Res., 52, 8138-8158, https://doi.org/10.1002/2016WR018675, 2016.

Hayakawa Y., Imaizumi, F., Hotta, N., and Tsunetaka, H.: Towards Long-Lasting Disaster Mitigation Following a Mega-landslide: High-Definition Topographic Measurements of Sediment Production by Debris Flows in a Steep Headwater Channel, in: Geomorphology and Society, Springer, 2016.

Horn, B. K. P.: Hill shading and the reflectance map, Proc. IEEE, 69, 14-47, https://doi.org/10.1109/PROC.1981.11918, 1981.

Hu, K., Wei, F., and Li, Y.: Real-time measurement and preliminary analysis of debris-flow impact force at Jiangjia Ravine, China, Earth Surf. Process. Landf, 36, 1268-1278, 2011.

Hungr, O.: Classification and terminology, in: Debris-flow Hazards and Related Phenomena, Praxis, Springer, Berlin Heidelberg, 106-134, 2005.

Hungr, O., McDougall, S., Wise, M., and Cullen, M.: Magnitudefrequency relationships of debris flows and debris avalanches in relation to slope relief, Geomorphology, 96, 355-365, 2008.

Hürlimann, M., Abancó, C., Moya, J., and Vilajosana, I.: Results and experiences gathered at the Rebaixader debris-flow monitoring site, Central Pyrenees, Spain, Landslides, 11, 939-953, https://doi.org/10.1007/s10346-013-0452-y, 2014.

Hürlimann, M., McArdell, B. W., and Rickli, C.: Field and laboratory analysis of the runout characteristics of hillslope debris flows in Switzerland, Geomorphology, 232, 20-32, https://doi.org/10.1016/j.geomorph.2014.11.030, 2015.

Imaizumi, F., Tsuchiya, S., and Ohsaka, O.: Behaviour of debris flows located in a mountainous torrent on the Ohya landslide, Japan, Can. Geotech. J., 42, 919-931, 2005.

Imaizumi, F., Sidle, R. C., Tsuchiya, S., and Ohsaka, O.: Hydrogeomorphic processes in a steep debris flow initiation zone, Geophys. Res. Lett., 33, L10404, https://doi.org/10.1029/2006GL026250, 2006.

Imaizumi, F., Nishii, R., Murakami, W., and Daimaru, H.: Parallel retreat of rock slopes underlain by alternation of strata, Geomorphology, 238, 27-36, 2015.

Imaizumi, F., Trappman, D., Matsuoka, N., Tsuchiya, S., Ohsaka, O., and Stoffel, M.: Biographical sketch of a giant: deciphering recent debris-flow dynamics from Ohya landslide body (Japanese Alps), Geomorphology, 272, 102-114, https://doi.org/10.1016/j.geomorph.2015.11.008, 2016a.

Imaizumi, F., Tsuchiya, S., and Ohsaka, O.: Behavior of boulders within a debris flow initiation zone, Int. J. Erosion Control Eng., 9, 91-100, https://doi.org/10.13101/ijece.9.91, $2016 \mathrm{~b}$.

Imaizumi F., Tsuchiya, S., and Ohsaka, O.: Field observations of debris-flow initiation processes on sediment deposits in a previous deep-seated landslide site, J. Mount. Sci, 13, 213-222, https://doi.org/10.1007/s11629-015-3345-9, $2016 \mathrm{c}$.

Jakob, M., Bovis, M., and Oden, M.: The significance of channel recharge rates for estimating debris-flow magnitude and frequency, Earth Surf. Process. Landf., 30, 755-766, 2005.

Kean, J. W., McCoy, S. W., Tucker, G. E., Staley, D. M., and Coe, J. A.: Runoff-generated debris flows: Observations and modeling of surge initiation, magnitude, and frequency, J. Geophys. Res., 18, 2190-2207, https://doi.org/10.1002/jgrf.20148, 2013.

Kirkby, M. J. and Statham, I.: Surface stone movement and scree formation, J. Geology, 83, 349-362, 1975. 
Lanzoni, S. Gregoretti, C., and Stancanelli, L. M.: Coarse-grained debris flow dynamics on erodible beds, J. Geophys. Res., 122, 592-614, https://doi.org/10.1002/2016JF004046, 2017.

Lin, P. S., Lin, J. Y., Hung, J. C., and Yang, M. D.: Assessing debrisflow hazard in a watershed in Taiwan, Eng. Geol., 66, 295-313, https://doi.org/10.1016/S0013-7952(02)00105-9, 2002.

Loye, A., Jaboyedoff, M., and Pedrazzini, A.: Identification of potential rockfall source areas at a regional scale using a DEMbased geomorphometric analysis, Nat. Hazards Earth Syst. Sci., 9, 1643-1653, https://doi.org/10.5194/nhess-9-1643-2009, 2009.

Mangeney, A., Bouchut, F., Thomas, N., Vilotte, J. P., and Bristeau, M. O.: Numerical modeling of self-channeling granular flows and of their levee-channel deposits, J. Geophys. Res, 112, F02017, https://doi.org/10.1029/2006JF000469, 2007.

March, L., Arattano, M., and Deganutti, A. M.: Ten years of debrisflow monitoring in the Morcardo Torrent (Italian Alps), Geomorphology, 46, 1-17, 2002.

McArdell, B. W., Bartelt, P., and Kowalski, J.: Field observations of basal forces and fluid pore pressure in a debris flow, Geophys. Res Lett., 34, L07406, https://doi.org/10.1029/2006GL029183, 2007.

McCoy, S. W., Kean, J. W., Coe, J. A., Staley, D. M., Wasklewicz, T. A., and Tucker, G. E.: Evolution of a natural debris flow: In situ measurements of flow dynamics, video imagery, and terrestrial laser scanning, Geology, 38, 735-738, 2010.

McCoy, S. W., Kean, J. W., Coe, J. A., Tucker, G. E., Staley, D. M., and Wasklewicz, T. A.: Sediment entrainment by debris flows: In situ measurements from the headwaters of a steep catchment, J. Geophys. Res., 117, F03016, https://doi.org/10.1029/2011JF002278, 2012.

McCoy, S.W., Tucker, G. E., Kean, J. W., and Coe, J. A.: Field measurement of basal forces generated by erosive debris flows, J. Geophys. Res., 118, 589-602, https://doi.org/10.1002/jgrf.20041, 2013.

Obanawa, H. and Matsukura, Y.: Cliff retreat and talus development at the caldera wall of Mount St. Helens: Computer simulation using a mathematical model, Geomorphology, 97, 697-711, 2008.

Okano, K., Suwa, H., and Kanno, T.: Characterization of debris flows by rainstorm condition at a torrent on the Mount Yakedake volcano, Japan, Geomorphology, 136, 88-94, 2012.

Pareschi, M. T., Santacroce, R., Sulpizio, R., and Zanchetta, G.: Volcaniclastic debris flows in the Clanio Vally (Campania, Italy): insights for the assessment of hazard potential, Geomorphology, 43, 219-231, 2002.

Pirotti, F. and Tarolli, P.: Suitability of LiDAR point density and derived landform curvature maps for channel network extraction, Hydrol. Process., 24, 1187-1197, https://doi.org/10.1002/hyp.7582, 2010.

Prancevic, J. P., Lamb, M. P., and Fuller, B. M.: Incipient sediment motion across the river to debris-flow transition, Geology, 41, 191-194, https://doi.org/10.1130/G34927.1, 2014.

Schlunegger, F., Badoux, A., McArdell, B. W., Gwerder, C., Schnydrig, D., Rieke-Zapp, D., and Molnar, P.: Limits of sediment transfer in an alpine debris-flow catchment, Illgraben, Switzerland, Quat. Sci. Rev., 28, 1097-1105, 2009.
Schmidt, J. and Andrew, R.: Multi-scale landform characterization, Area, 37.3, 341-350, 2005.

Staley, D. N., Wasklewicz, T. A., and Blaszczynsk, J. S.: Surficial patterns of debris flow deposition on alluvial fans in Death Valley, CA using airborne laser swath mapping data, Geomorphology, 74, 152-163, 2006.

Staley, D. N., Wasklewicz, T. A., and Kean, J. W.: Characterizing the primary material sources and dominant erosional processes for post-fire debris-flow initiation in a headwater basin using multi-temporal terrestrial laser scanning data, Geomorphology, 214, 324-338, 2014.

Takahashi, T.: An occurrence mechanism of mud-debris flows, and their characteristics in motion, Annuals, DPRI, 23B2, 405-435, 1977 (in Japanese).

Takahashi, T.: Mechanical characteristics of debris flow, J. Hydraul. Div., ASCE, 104, 1153-1169, 1978.

Takahashi, T.: Debris flow, IAHR Monograph, A.A. Balkema, Rotterdam, 1991.

Takahashi, T.: Debris flow: Mechanics, Prediction and Countermeasures, Taylor \& Francis, Leiden, 448 p., 2007.

Takahashi, T.: Debris flow, CRC Press/Balkema, EH Leiden, the Netherlands, 2014.

Takahashi, T. and Tsujimoto, H.: A mechanical model for Merapitype pyroclastic flow, J. Volcanol. Geotherm. Res., 98, 91-115, https://doi.org/10.1016/S0377-0273(99)00193-6, 2000.

Theule, J. I., Liébault, F., Loye, A., Laigle, D., and Jaboyedoff, M.: Sediment budget monitoring of debris-flow and bedload transport in the Manival Torrent, SE France, Nat. Hazards Earth Syst. Sci., 12, 731-749, https://doi.org/10.5194/nhess-12-7312012, 2012.

Tsuchiya, S. and Imaizumi, F.: Large sediment movement caused by the catastrophic Ohya-kuzure landslide, J. Dis. Sci., 3, 257-263, 2010 .

VanDine, D. F.: Debris flows and debris torrents in the southern Canadian Cordillera, Can. Geotech. J., 22, 44-62, 1985.

Watanabe, S.: Influence of the mixing ratio of water to sediment on the threshold slope of debris flow: a laboratory experiment, Trans. Jpn. Geomorph. Union, 15, 349-369, 1994 (in Japanese with English abstract).

Whipple, K. X. and Dunne, T.: The influence of debris-flow rheology on fan morphology, Owens Valley, California, Geol. Soc. Am. Bull., 104, 887-900, 1992.

Yamashita, S. and Miyamoto, K.: Sediment Problems: Strategies for Monitoring, Prediction and Control, Proceedings of the Yokohama Symposium, IAHS Publ., 217, 67-74, 1993.

Zhang, S.: A comprehensive approach to the observation and prevention of debris flows in China, Nat. Hazards, 7, 1-23, 1993.

Zhou, G. G. D., Cui, P., Tang, J. B., Chen, H. Y., Zou, Q., and Sun, Q. C.: Experimental study on the triggering mechanisms and kinematic properties of large debris flows in Wenjia Gully, Eng. Geol., 194, 52-61, https://doi.org/10.1016/j.enggeo.2014.10.021, 2015 